\title{
PENGGUNAAN METODE PEMBELAJARAN DRILL TERHADAP PERKEMBANGAN ARTIKULASI ANAK TUNARUNGU
}

\author{
Arifah Nnurhadiyati \\ IKIP PGRI Jember \\ arifah221@gmail.com
}

\begin{abstract}
ABSTRAK
Penelitian ini digunakan untuk meigkatkan kemampuan artikulasi pada anak tunarungu siswa sekolah dasar kelas 2 di SDN Kebonsari 5 Jember melalui metode pembelajaran Drill. Subjek penelitian ini berjumlah 6 orang yaitu 3 siswa laki-laki dan 3 siswa perempuan. Teknik pegumpulan data menggunakan teknik observasi dan tes kemampuan artikulasi. Analisis data yang digunakan yakni teknik komparatif yaitu membandingkan hasil pre tes dan pos tes. Proses peningkatan kemampuan artikulasi dilakukan dari melakukan pre tes untuk mengetahui kemampuan awal siswa. Pre tes menujukkan bahwa subjek belum mencapai KKM yang ditentukan yaitu 60. Kemudian dilakuakan pelatihan yang menggunakan metode Drill atau pengulangan. Setelah dilakukan beberapa kali pelatihan yang dilakukan. Hasil post test menujukkan ketiga siswa itu mengalami peningkatan nilai. Dari yang awalnya diangka 50 kebawah sekarang menjadi 60 keatas. Selanjutnya ditunjukkan pada hasil $\mathrm{Zh}(2,05)$ lebih besar dari pada nilai Z tabel 5\% (1,96), atau $\mathrm{Zh}(2,05)>\mathrm{Z}$ tabel $(1,96)$, maka Ho ditolak, yang berarti terdapat pengaruh metode pembelajaran dirll terhadap perkembangan artikulasi anak tunarungu. Simpulan, bahwa terdapat pengaruh yang signigikan antara metode pembelajaran Drill terhadap perkembangan artikulasi anak tunarungu.
\end{abstract}

Kata Kunci: Metode Drill, Artikulasi, Tunarungu

\section{ABSTRACT}

This study was used to improve the articulation ability of deaf children of grade 2 elementary school students at SDN Kebonsari 5 Jember through the Drill learning method. The subject of this research supports 6 people, namely 3 male students and 3 female students. Data collection techniques using collection techniques and tests of articulation skills. Analysis of the data used is a comparative technique that compares the results of pre-test and post test. The process of enhancing the ability of articulation is carried out from the pre-test to determine the students' initial abilities. The pre-test shows that the subject has not yet reached the specified KKM, which is 60. Then training is carried out using the Drill method or repetition. After a number of training sessions were carried out. Post test results show students who have increased grades. From the initial number 50 and below, it is now 60 and above. Furthermore, considering the results of $Z \mathrm{~h}$ (2.05) is greater than the value of $Z$ table $5 \%$ (1.96), or Zh (2.05)> Z table (1.96), then Ho is rejected, which means it needs to be added to learning methods dirll towards the development of articulation of deaf children. Conclusion, that is the significance of the significant importance between Bor learning methods on the development of articulation of deaf children.

Keywords: Drill, Articulation, Deaf Method 


\section{PENDAHULUAN}

Manusia sebagai mahluk sosial tentu tidak bisa dipisahkan dengan komuikasi. Melalui komunikasi kita bisa berhubunga dengan orang lain. Untuk berkomunikasi dibutuhkan artikulasi yang jelas sehingga kita dapat berkomunikasi dua arah. Apalagi untuk anak tunarugu. Murni Winarsih (2007) mengemukakan bahwa tunarungu adalah seseorang yang mengalami kekurangan atau kemampuan mendengar baik sebagian atau seluruhnya yang diakibatkan oleh tidak berfungsinya sebagian atau seluruh alat pendengaran, sehingga ia tidak dapat memfungsikan alat pendengarannya dengan baik dalam kehidupan seharihari, yang akan berdampak pada kemampuan berbahasa sebagai alat penjunjangdalam berkomunikasi. Dalam penelitian yang dilakukan oleh sari (2014) bahwa Klasifkasi anak tunarungu dapat dilihat dari tingkat kehilangan ketajaman pendengarannya. Kehilangan ketajaman pendengaran tersebut dikelompokkan menjadi kelompok tuli (deafness) dan kelompok lemah pendengaran (hard of hearing).

Dampak langsung dari ketunarunguan adalah terhambatnya komunikasi yang bersifat verbal / lisan, baik secara ekspresif (berbicara) maupun reseptif (memahami pembicaraan orang lain), sehingga anak dengan hambatan tunarungu akan mengalami kesulitan dalam berkomunikasi dengan lingkungan orang mendengar yang pada umumnya menggunakan bahasa verbal sebagai alat berkomunikasi. Hambatan dalam berkomunikasi tersebut, berakibat juga dalam memperoleh informasi sehingga akan sangat berdamapak pada proses pendidikan dan pembelajaran anak tunarungu. Namun demikian anak tunarungu memiliki potensi untuk belajar berbicara dan berbahasa. Anak tungarungu memerlukan layanan khusus untuk mengembangkan kemampuan berbicara dan berbahasa, sehingga dapat meminimalisir dampak dari ketunarunguan yang dialaminya.

Kosakata atau perbendaharaan kata adalah kata-kata yang segera akan kita ketahui artinya bila mendengarnya kembali, walaupun jarang atau tidak pernah digunakan lagi dalam percakapan atau tulisan kita sendiri. Penguasaan kosakata penting dikuasai setiap orang, karena sebagai alat untuk berkomunikasi dalam menyatakan pikiran, perasaan, pengetahuan, dan pengalaman yang diperoleh. Dan tidak kurang pentingnya, penguasaan kosakata digunakan menanggapi pertanyaan, menjawab pertanyaan dari gagasan orang lain (Keraf, 1988). Untuk mengetahui kata yang diucapkan tentu memerlukan artkiluasi yang jelas. Jika artikulasi tidak jelas, tidak menutup kemugkinan orang lain tidak akan mengetahui apa dikatan.

Artikulasi merupakan suatu pengucapan kata dengan mulut supaya terdengar dengan baik serta benar juga jelas, menjadikan telinga pendengar atau juga penonton itu dapat mengerti terhadap kata-kata yang diucapkan. Oleh karena itu, artikulasi sangat dibutuhkan bagi anak tunarungu dalam komunikasi dan perlu dilatih terus-menerus.

Metode Drill adalah suatu metode dalam pembelajaan dengan melatih siswapada bahan yang sudah diajarkan/ berikan agar memiliki kemampuan atau ketrampilan dari apa yang telah dipelajari (Sudjana, 1995). Metode Drill dipilih karena mudah diterapkan dan diterima oleh anak-anak tunarungu. Pengulangan yang dilakukan akan mempermudah anak untuk mengucapkan kata dengan jelas dan benar, sehingga akan memepermudah komunikasi denga orang lain. Metode Drill ini dilakukan dengan melafalkan kata secara perlahan dan jelas. Sehingga memudahkan anak untuk menirukan kata yang diucapkan oleh pengajar. Kata yang diajarkan pertama kali mencakup kata yang digunakan sehari-hari. Membelajaran dilakuka selama 8 kali pertemuan dengan kata yang semakin ditingkatkan kesulitannya. 
Berdasarkan uraian di atas, melalui metode pembelajaran Drill dapat meninngkatkan kemampuan artikulasi siswa. Berdasarkan latar belakang di atas. Perlu dilakukan penelitian lebih lajut megenai "Pengaruh Penggunaan Metode Pembelajaran Drill Terhadap Perkembangan Artikulasi Anak Tunarungu Di Sekolah Dasar”

\section{METODE PENELITIAN}

Desain penelitian yang digunakan adalah pra-eksperimen dengan bentuk "one group pre test post test design". Desain ini melibatkan satu kelompok, namun pengukuran atau tes dilakukan sebanyak 2 kali yaitu pada awal (O1) dan akhir(O2) perlakuan untuk mendapatkan tingkat efektifitas perlakuan X (Anggoro,2007). Teknik pengumpulan data pada penelitian ini melalui metode tes dan metode observasi. Analisis data adalah cara yang digunakan dalam proses penyederhanaan data kedalam data yang lebih mudah dibaca dan dipresentasikan dengan menggunakan rumus statistik non parametrik jenis uji tanda (sign test $\mathrm{ZH}$ )

\section{HASIL PENELITIAN}

Dari perolehan hasil pre test 1 kali, post tes 1 kali dan intervens 8 kali maka diperoleh data dalam tabel sebagai berikut:

\section{Tabel 1}

\section{Pretest Kemampuan Membaca dan Artikulasi Siswa}

\begin{tabular}{|c|c|c|c|c|}
\hline \multirow{2}{*}{$\begin{array}{l}\text { Nama } \\
\text { Siswa }\end{array}$} & \multicolumn{3}{|c|}{ Keterampilan Artikulasi } & \multirow{2}{*}{$\begin{array}{c}\text { Jumlah } \\
\text { Skor }\end{array}$} \\
\hline & $\begin{array}{c}\text { Kemampuan } \\
\text { Membaca Kalimat } \\
\text { Sederhana }\end{array}$ & $\begin{array}{c}\text { Kemampuan Melafalkan } \\
\text { Huruf Konsonan }\end{array}$ & $\begin{array}{c}\text { Kemampuan Pemahaman Siswa } \\
\text { Terhadap Sebuah Kalimat }\end{array}$ & \\
\hline $\mathrm{AG}$ & 12 & 14 & 13 & 39 \\
\hline AP & 14 & 14 & 11 & 39 \\
\hline $\mathrm{DS}$ & 13 & 16 & 12 & 41 \\
\hline OS & 11 & 15 & 13 & 39 \\
\hline NS & 12 & 15 & 13 & 40 \\
\hline SJ & 13 & 13 & 15 & 41 \\
\hline
\end{tabular}

Hasil Postest Kemampuan Membaca dan Artikulasi Siswa Dalam Mengucapkan Beberapa Kata Yang Diberikan Kepada Anak Tuarungu SDN 5 Kebonsari Jember

Tabel 2

\section{Postest Kemampuan Membaca dan Artikulasi Siswa}

\begin{tabular}{|c|c|c|c|c|}
\hline \multirow{2}{*}{$\begin{array}{l}\text { Nama } \\
\text { Siswa }\end{array}$} & \multicolumn{3}{|c|}{ Keterampilan Artikulasi } & \multirow{2}{*}{$\begin{array}{c}\text { Jumlah } \\
\text { Skor }\end{array}$} \\
\hline & $\begin{array}{c}\text { Kemampuan } \\
\text { Membaca Kalimat } \\
\text { Sederhana }\end{array}$ & $\begin{array}{c}\text { Kemampuan Melafalkan } \\
\text { Huruf Konsonan }\end{array}$ & $\begin{array}{l}\text { Kemampuan Pemahaman Siswa } \\
\text { Terhadap Sebuah Kalimat }\end{array}$ & \\
\hline $\mathrm{AG}$ & 18 & 19 & 18 & 55 \\
\hline AP & 17 & 19 & 18 & 54 \\
\hline DS & 14 & 18 & 18 & 50 \\
\hline OS & 17 & 16 & 20 & 53 \\
\hline NS & 18 & 16 & 17 & 51 \\
\hline SP & 18 & 17 & 16 & 51 \\
\hline
\end{tabular}


Rekapitulasi Data Hasil Pretest dan Postest Siswa Dalam Mengucapkan Beberapa Kata Yang Diberikan Kepada Anak Tuarungu SDN 5 Kebonsari Jember

Tabel 3

Hasil Pretest dan Postest Siswsa

\begin{tabular}{cccc}
\hline No. & $\begin{array}{c}\text { Nama } \\
\text { Siswa }\end{array}$ & Pretest & Postest \\
\hline 1. & AG & 39 & 55 \\
\hline 2. & AP & 39 & 54 \\
\hline 3. & DS & 41 & 50 \\
\hline 4. & OS & 39 & 53 \\
\hline 5. & NS & 40 & 51 \\
\hline 6. & SP & 41 & 51 \\
\hline Rata-Rata & 39,8 & 52,3 \\
\hline
\end{tabular}

Tabel Kerja Perubahan Hasil Pretest dan Posttest Siswa Dalam Mengucapkan Beberapa Kata Yang Diberikan Kepada Anak Tuarungu SDN 5 Kebonsari Jember

Tabel 4

\section{Hasil Pretest dan Postest dalam Mengucapkan Beberapa Kata}

\begin{tabular}{|c|c|c|c|}
\hline \multirow[t]{2}{*}{ Nama } & \multicolumn{2}{|c|}{ Skor } & \multirow{2}{*}{$\begin{array}{c}\text { Perubahan } \\
\text { Tanda } \\
\left(\mathrm{O}_{2}-\mathrm{O}_{1}\right)\end{array}$} \\
\hline & $\begin{array}{c}\text { Pretest } \\
\left(\mathrm{O}_{1}\right)\end{array}$ & $\begin{array}{c}\text { Posttest } \\
\left(\mathrm{O}_{2}\right)\end{array}$ & \\
\hline $\mathrm{AG}$ & 39 & 55 & + \\
\hline AP & 39 & 54 & + \\
\hline DS & 41 & 50 & + \\
\hline OS & 39 & 53 & + \\
\hline NS & 40 & 51 & + \\
\hline SP & 41 & 51 & + \\
\hline \multicolumn{3}{|c|}{ Jumlah Tanda Plus (+) } & 6 \\
\hline
\end{tabular}

Data-data hasil penelitian yang berupa nilai pre tes dan pos tes yang telah dimasukkan ke dalam table kerja perubahan di atas kemudian dianalisis dengan menggunakan rumus sign test dengan keterangan sebagai berikut:

Hasil tabel kerja perubahan di atas kemudian akan diukur dengan rumus uji tanda atau "sign test". Adapun rumusnya sebagai berikut :

Menentukan Mean $(\mu)$

$$
Z h=\frac{X-\mu}{\sigma}
$$

$$
\begin{aligned}
(\mu) & =\mathrm{n} \cdot \mathrm{p} \\
& =5 \cdot 0,5 \\
& =2,5
\end{aligned}
$$

Menentukan Standat Deviasi $(\sigma)$

$(\sigma)=\sqrt{\text { n.p.q }}$ 


$$
\begin{aligned}
& =\sqrt{6 \cdot 0,5 \cdot 0,5} \\
& =\sqrt{1,5} \\
& =1,22
\end{aligned}
$$

Dari hasil pretest dan posttest tentang pengaruh model induktif kata bergambar tanda positif lebih besar dari pada pada mean, maka nilai $\mathrm{X}$ terletak di sebelah kanan kurva normal yaitu 5,5, sehingga digunakan rumus :

Pengujian 2 sisi $(\alpha=5 \%, Z$ tabel $=1,96)$

Diketahui : $X=$ jumlah tanda plus $(+)-p$

$$
\begin{aligned}
& =6-0,5 \\
& =5,5 \\
\mu & =3 \\
\sigma & =1,22
\end{aligned}
$$

Dengan uji tanda (sign test) sebagai berikut : $Z h=\frac{X-\mu}{\sigma}$

$$
\begin{aligned}
& =\frac{5,5-3}{1,22} \\
& =\frac{2,5}{1,22} \\
& =2,05
\end{aligned}
$$

Nilai $\mathrm{Zh}(2,05)$ lebih besar dari pada nilai Z tabel 5\% (1,96), atau Zh $(2,05)>\mathrm{Z}$ tabel $(1,96)$, maka Ho ditolak, yang berbunyi ada pengaruh Penggunaan Metode Pembelajaran Drill Terhadap Perkembangan Artikulasi Anak Tunarungu Di Sekolah Inklusi SDN Kebonsari 5 Jember

\section{PEMBAHASAN}

Hasil analisis data menunjukkan bahwa nilai $\mathrm{Z}$ yang diperoleh dalam hitungan 2,05 lebih besar dari nilai kritis 5\% yaitu 1,96 sehingga diketahui bahwa ada pengaruh yang signifikan antara metode pembelajaran Drill dan perkembngan artikulasi anak tunarungu di SDN Kebonsari 5 Jember. Hasil yang sama juga bahwa metode Drill terbukti dapat meningkatkan kemampuan siswa tunarungu dalam mengetahui proses pembuatan makrame.

Keterbatasan tunarungu dalam mendengar berakibat pada minimnya perbendaharaan kata yang menjadikan pula keterbatasan dalam menulis. Model pembelajaran juga harus disesuaikan dengan karakteristik anak tunarungu. Salah satu teori pembelajaran adalah dengan cara melakukan pengulangan. Semakin sering pengulangan maka materi akan semakin dikuasai.

Bunyi bahasa yang diajarkan dimulai dari deretan bunyi paling depan/muka di mulut, karena bunyi-bunyi tersebut paling mudah dilihat dan ditiru, yaitu kelompok konsonan bilabial ( $\mathrm{p}, \mathrm{b}, \mathrm{m}$ dan w). Setelah konsonan bilabial dikuasai, dilanjutkan pada konsonan dental (l, r, t, d dan $\mathrm{n}$ ), kemudian konsonan velar (k,g dan ng), dan selanjutnya konsonan palatal (c, j, ny, y dan s).

Huruf tersebut dianggap kunci dalam sebuah kata. Pada anak tunarungu huruf tersebutlah yang diajarkan pertama kali. Melalui huruf tersebut bisa didapatkan artikulasi yag 
jelas pada sebuah kata. Pembelajaran dilakuka bersama-sama, metode ini bisa diterapkan pada semua materi pembelajaran di kelas. Yang paling utama yaitu, pada pelajaran Bahsa Indonesia. Anak akan diajarkan untuk mandiri dan tidak bergantung pada bahasa isyarat yag sulit dimengerti orang lain.h

Anak tunarungu mengalami gangguan pendengaran yang mengakibatkan terbatasnya pemerolehan informasi sehingga mengalami hambatan dalam berkomunikasi. Hal ini mengakibatkan anak tunarungu cenderung menggunakan bahasa isyarat yang mudah mereka gunakan dibandingkan mengguakan kata atau bahasa oral untuk berkomunikasi dengan orang lain. Oleh karean itu, sejak dini mungkin anak tunarungu harus diajarkan bahasa oral dengan artikulasi yang jelas, dibadingkan dibiasakan untuk meggunakan bahasa isyarat.

\section{SIMPULAN}

Berdasarkan hasil penelitian ini dapat disimpulkan bahwa Penerapan model pembelajaran Drill berpengaruh secara signifikan terhadap artikulasi anak SDN Kebonsari 5 Jember.

\section{DAFTAR PUSTAKA}

Anggoro, M., T. (2007). Metode Penelitian. Jakarta: Universitas Terbuka.

Arikunto, S. (2006). ProsedurPenelitian. Jakarta: Rineka Cipta

Saleh, S. (1996). Statistik Nonparametrik. Yogyakarta: BPFE

Somad, P \& Hernawati, T. (1996). Ortopedagogik Anak Tunarungu. Jakarta: Departemen Pendidikan Dan Kebudayaan Direktorat Jenderal Pendidikan Tinggi Proyek Pendidikan Tenaga Guru.

Winarsih, M. (2007). Intervensi Dini Bagi Anak Tunarungu dalam Pemerolehan Bahasa. Depdikbud. Dirjen Dikti. Jakarta.

Sugiyono. (2010). Metode Penelitian Kuantitaf Kualitatif dan $R \& G$. Bandung: Alfabeta

Sudjana, N. (1995). Dasar-dasar Proses Belajar Mengajar. Bandung: Sinar Baru Algensindo. 